\title{
Mortality due to respiratory diseases in the elderly after influenza vaccination campaigns in the Federal District, Brazil, 1996-2009*
}

\author{
Mortalidade por doenças respiratórias em idosos após campanhas vacinais \\ contra influenza no Distrito Federal, Brasil, 1996-2009
}

\author{
Francisca Magalhães Scoralick, Luciana Paganini Piazzolla, Liana Laura Pires, \\ Cleudsom Neri, Wladimir Kummer de Paula
}

\begin{abstract}
Objective: To compare mortality rates due to respiratory diseases among elderly individuals residing in the Federal District of Brasília, Brazil, prior to and after the implementation of a national influenza vaccination campaign. Methods: This was an ecological time series analysis. Data regarding the population of individuals who were over 60 years of age between 1996 and 2009 were obtained from official databases. The variables of interest were the crude mortality rate (CMR), the mortality rate due to the respiratory disease (MRRD), and the proportional mortality ratio (PMR) for respiratory diseases. We performed a qualitative analysis of the data for the period prior to and after the implementation of the vaccination campaign (1996-1999 and 2000-2009, respectively). Results: The CMR increased with advancing age. Over the course of the study period, we observed reductions in the CMR in all of the age brackets studied, particularly among those aged 80 years or older. Reductions in the MRRD were also found in all of the age groups, especially in those aged 80 years or older. In addition, there was a decrease in the PMR for respiratory diseases in all age groups throughout the study period. The most pronounced decrease in the PMR for respiratory diseases in the $\geq 70$ year age bracket occurred in 2000 (immediately following the implementation of the national vaccination campaign); in 2001, that rate increased in all age groups, despite the greater adherence to the vaccination campaign in comparison with that recorded for 2000. Conclusions: Influenza vaccination appears to have a positive impact on the prevention of mortality due to respiratory diseases, particularly in the population aged 70 or over.
\end{abstract}

Keywords: Influenza, human/mortality; Influenza, human/epidemiology; Influenza vaccines.

\section{Resumo}

Objetivo: Comparar os índices de mortalidade por doenças respiratórias em idosos residentes no Distrito Federal (DF) antes e após a implantação da campanha nacional de vacinação contra influenza. Métodos: Estudo ecológico de séries temporais. Os dados referentes à população do DF acima de 60 anos entre 1996 e 2009 foram obtidos de bancos de dados oficiais. As variáveis estudadas foram o coeficiente de mortalidade geral (CMG), coeficiente de mortalidade por doenças respiratórias (CMDR) e índice de mortalidade por causas respiratórias (IMR). Foi realizada uma análise qualitativa dos dados referentes ao período antes e após a implantação da campanha de vacinação (1996-1999 e 2000-2009, respectivamente). Resultados: 0 CMG aumentou com o incremento da faixa etária. No decorrer do período do estudo, houve uma redução no CMG em todas as faixas etárias, especialmente naquela com 80 anos ou mais. Houve redução do CMDR em todos os grupos etários, especialmente naqueles com mais de 80 anos. 0 IMR mostrou uma redução em todas as faixas etárias por todo o período estudado. Em 2000, ano imediatamente subsequente à primeira campanha vacinal, a redução do IMR foi mais pronunciada na faixa etária $\geq 70$ anos; em 2001, houve um aumento do IMR em todas as faixas etárias, apesar da maior adesão à campanha de vacinação em relação a 2000. Conclusões: A vacinação contra a influenza parece influir positivamente na prevenção da mortalidade por doenças respiratórias, particularmente nos idosos com 70 anos ou mais

Descritores: Influenza humana/mortalidade; Influenza humana/epidemiologia; Vacinas contra influenza.

\footnotetext{
* Study carried out carried out under the auspices of the Graduate Program in Health Sciences, University of Brasilia, Brasilia, Brazil. Correspondence to: Francisca Magalhães Scoralick. Hospital Regional da Asa Norte, Ambulatório de Geriatria e Gerontologia, SMHN Qd. 101, Asa Norte, CEP 70710-910, Brasília, DF, Brasil.
}

Tel.55613327-8471.E-mail: franciscascoralick@gmail.com

Financial support: None.

Submitted: 15 December 2012. Accepted, after review: 15 January 2013. 


\section{Introduction}

Influenza is an acute respiratory infection caused by Myxovirus influenzae. Worldwide, influenza causes greater morbidity than does any other infectious processes. Typically self-limiting, influenza is seen as having little relevance in its uncomplicated form and resolves spontaneously in approximately one week. ${ }^{(1-3)}$ The typical clinical manifestations of the uncomplicated form include fever, odynophagia, cough, myalgia, rhinitis, headache, and asthenia. In the elderly population, influenza can lead to complications, primarily viral or bacterial pneumonia. ${ }^{(4)}$

During influenza epidemics, the disease spreads rapidly and is responsible for high morbidity and mortality, especially in the elderly. The complications of influenza are responsible for a significant number of hospitalizations in Brazil. In 2009, 851,044 hospitalizations for influenza and pneumonia were recorded by the Hospital Information Service of the Brazilian Unified Health Care System, a figure that is $10 \%$ higher than was the average for the five years preceding that. Of all hospitalizations, 24\% were for individuals 60 years of age or older. ${ }^{(3)}$

The elderly are the most vulnerable group to influenza, because advanced age is associated with a higher prevalence of chronic degenerative diseases and with immunological impairment. ${ }^{(5)}$ The primary prevention measure is influenza vaccination, as has been recommended by the World Health Organization since 1963. In Brazil, influenza vaccination has been made available for free to the elderly throughout the country by the Brazilian National Ministry of Health since 1999. The vaccination campaign for seniors in Brazil represents a large public investment, involving an expenditure of about $\mathrm{R} \$ 130$ million per year in the purchase and application of the vaccine, as well as in dissemination campaigns. ${ }^{(6)}$

Various studies, especially those conducted in the northern hemisphere, have demonstrated that the influenza vaccine is effective in the elderly, reducing morbidity and mortality. ${ }^{(7,8)}$ In Brazil, one group of authors observed a reduction in mortality rates one year after the vaccine intervention in the state of São Paulo. ${ }^{(9)}$ However, another study observed that the rates of hospitalization and death for respiratory or circulatory diseases were not reduced by vaccination in the elderly population of the city of Fortaleza, Brazil. ${ }^{(10)}$ The objective of the present study was to compare mortality rates for respiratory diseases among elderly individuals residing in the Federal District of Brasília, Brazil, prior to and after the implementation of a national influenza vaccination campaign in 1999.

\section{Methods}

This was an ecological time series analysis involving data from the mortality records for all-cause mortality and mortality from respiratory disease in residents of Brasília who were over 60 years of age between 1996 and 2009; those data were obtained from the Mortality Database of the Brazilian National Ministry of Health Unified Health Care System. ${ }^{(11)}$

Estimates regarding the elderly population residing in Brasília, by age, were obtained from the Brazilian Institute of Geography and Statistics. ${ }^{(12)}$ In developing countries, the United Nations considers individuals 60 years of age or older as elderly. In Brazil, Law no. 8.842/9 also classifies a person 60 years of age or older as elderly. In the present study, the elderly were divided into three age groups: 60-69 years; 70-79 years; and $\geq 80$ years.

In order to determine the impact that influenza has on the community, we used the diagnoses of the following respiratory complications of viral infection: pneumonia; influenza; bronchitis; and chronic airway obstruction. For data collected up to 1997, we used the ninth revision of the International Classification of Diseases (ICD9), and, for data collected from 1998 onward, we used the 1CD-10. In the 1CD-9, the codes assigned to the aforementioned diagnoses are 480-486, 487, 490-491, and 495-496, whereas those same diagnoses are coded as J10-J15, J18, $\mathrm{J} 22$, J40-J42, and J44, respectively, in the ICD-10. Because COPD is prevalent in patients 60 years of age or older and is frequently complicated by viral infection, leading to hospitalization and eventually to death, ${ }^{(5)}$ it was included in the diagnoses.

We calculated the crude (all-cause) mortality rate (CMR) for each age group (60-69 years, 70-79 years, and $\geq 80$ years). In addition, we calculated the respiratory disease mortality rate (RDMR), on the basis of the classification described above, also for each of the three age groups. Subsequently, we calculated the proportional mortality ratio (PMR) for respiratory diseases, which is the ratio between the RDMR and the CMR. 
Data regarding vaccination coverage in the study population were obtained from the website of the Department of Information Technology of the Brazilian National Ministry of Health Unified Health Care System and tabulated according to the area of interest (i.e., Brasilia) in the specified period (1996-2009).

\section{Results}

Considering 1996 as the beginning of the analysis period, we found that the CMR increased with advancing age, from 20/1,000 population in the 60- to 69-year age group to 200/1,000 in the $\geq 80$-year age group (Figure 1). Over the study period (1996-2009), the CMR remained mostly stable in the 60- to 69-year age group and showed a slight reduction in the 70- to 79-year age group after the implementation of the national vaccination campaign in 1999. However, in the $\geq 80$-year age group, there were significant fluctuations in the CMR over that period. For that age group, despite the decrease in the CMR that occurred in 2000, the year following the implementation of the national vaccination campaign, the CMR increased gradually, reaching 200/1,000 population in 2006. It is of note that, in 2007, the CMR again showed a considerable reduction, greater than that observed in 2000 , reaching approximately 150/1,000 population, and, in 2009 (end of the analysis period), it reached 130/1,000 population. Therefore, as compared with the year immediately following the implementation of the national vaccination campaign, i.e., 2000, the CMR decreased in all three age groups, and the decrease was most pronounced in the $\geq 80$-year age group.

The analysis of the RDMR, as shown in Figure 2, indicates that this rate clearly decreased in all three age groups over the analysis period. We found that the RDMR did not fluctuate significantly in the 60- to 69-year age group but that, in 2000 , one year after the implementation of the national vaccination campaign, it decreased in the 70- to 79-year age group, a decrease followed by transient rises and then by a steady and mild decline until 2009. In the $\geq 80$-year age group, the RDMR fluctuated after 2000, with moderate increases in 2001 and 2002, followed by a decrease in 2003 and marked increases in 2004 and 2005. From 2007 to 2009, there was a progressive reduction in the RDMR, which, in 2009 , reached a value similar to that recorded for 2000 .

The analysis of the PMR curves revealed that there was a reduction in the PMR for respiratory

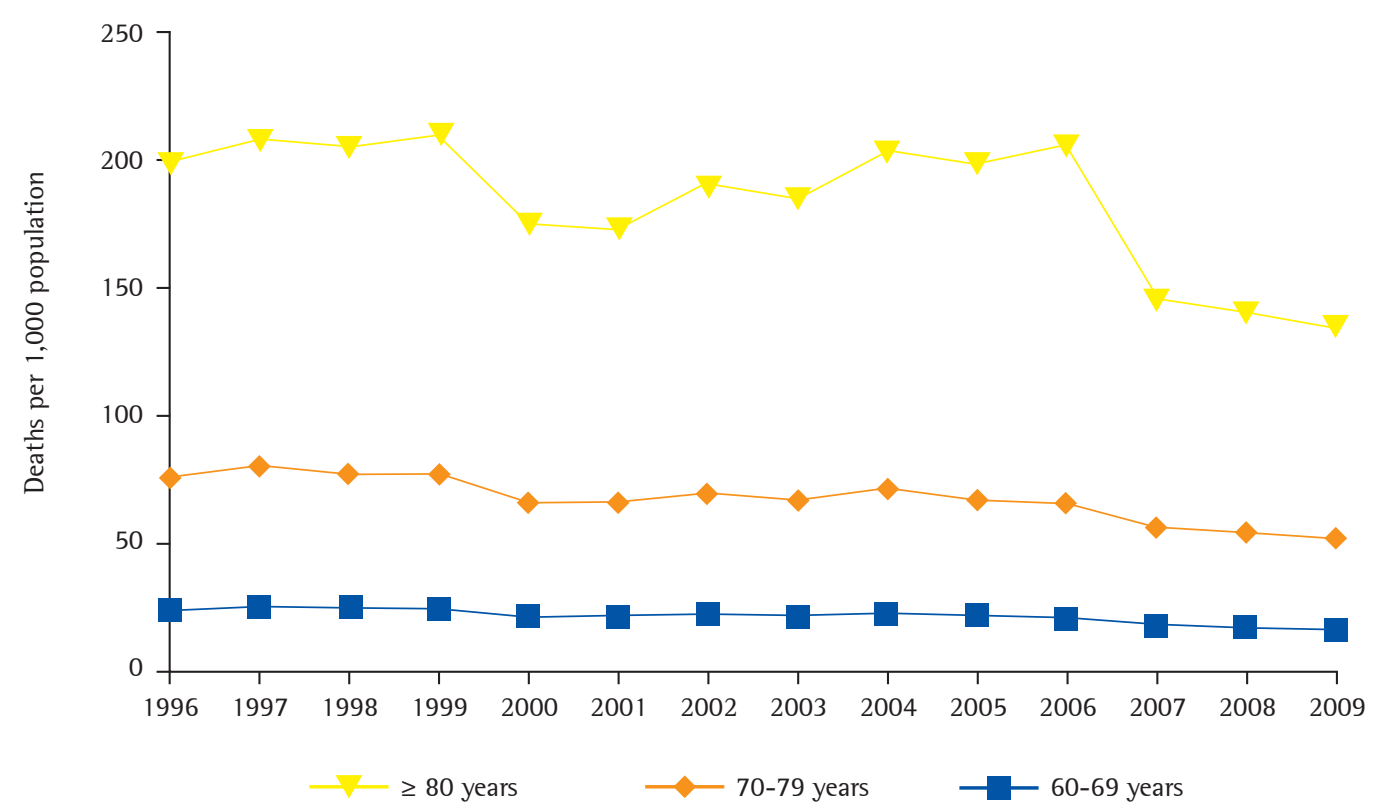

Figure 1 - Crude (all-cause) mortality rate (per 1,000 population) between 1996 and 2009 in the Federal District of Brasília, Brazil, by age group. 


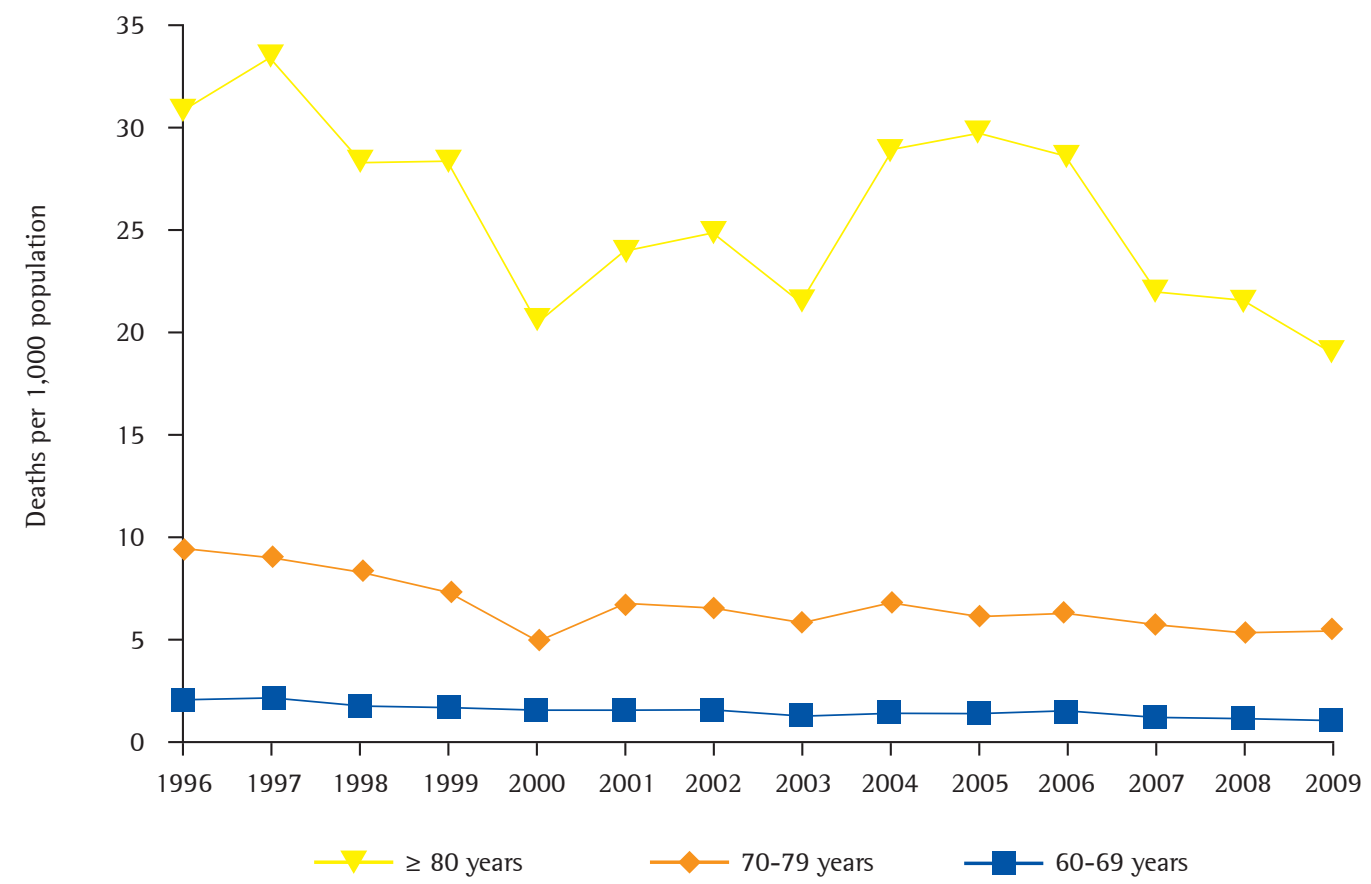

Figure 2 - Respiratory disease mortality rate per 1,000 population between 1996 and 2009 in the Federal District of Brasília, Brazil, by age group.

diseases between 1996 and 2009 for all of the age groups evaluated. However, in the 60- to 69-year age group, the PMR for respiratory diseases remained stable after 2000, whereas it continued to oscillate in the other two age groups, with occasional decreases and tendencies toward an increase throughout the period, although never again reaching the high values observed in 1996 (Figure 3).

Table 1 shows that influenza vaccination coverage decreased significantly in 2000 as compared with 1999, when the national vaccination campaign was implemented. After that, between 2001 and 2009, the level of coverage fluctuated, adherence increasing between 2001 and 2003, after which there were additional fluctuations.

\section{Discussion}

In Brasília, the elderly population increases every year. In the last decade, the Brazilian population over 60 years of age has grown by $41.6 \%$, and this growth was most significant in the $\geq 80$-year age group, which increased by $60.2 \% .^{(10)}$

Individuals 80 years of age or older, designated as the very elderly, exhibit a higher prevalence of comorbidities and are at a greater risk of decompensation of their comorbidities in response to a stressor, such as influenza. ${ }^{(5)}$ This could explain the progressive increase in mortality from influenza in this age group. Although there were fluctuations in the CMR and the RDMR, the results of the present study indicate that there was a reduction in mortality after the implementation of the national vaccination campaign. There was a greater reduction in the PMR for respiratory diseases in those 70 years of age or older, and this can be attributed to greater vaccination coverage in this population, as has also been observed by a group of authors in the state of Paraná, Brazil. ${ }^{(13)}$ The greatest decline in the PMR for respiratory diseases, in all three age groups, occurred in 2000, the first year after the implementation of the national vaccination campaign. In 2001, however, the data suggest an increase in mortality from respiratory diseases in all groups. This behavior can be explained by the pattern of adherence to the influenza vaccination campaign, which was lower in 2000. The non-participation of elderly individuals in immunization campaigns reflects their attitudes and beliefs about the risks and benefits of vaccination. ${ }^{(4,6,13)}$ 




Figure 3 - Proportional mortality ratio for respiratory diseases between 1996 and 2009 in the Federal District of Brasília, Brazil, by age group.

Table 1 - Influenza vaccination coverage (Brazilian National Immunization Campaign for Seniors) among individuals who were 60 years of age or older between 1999 and 2009. Federal District of Brasília, Brazil.

\begin{tabular}{|c|c|c|c|c|c|c|c|c|c|c|c|}
\hline \multirow{2}{*}{$\begin{array}{c}\text { Immunization against } \\
\text { influenza }\end{array}$} & \multicolumn{11}{|c|}{ Year } \\
\hline & 1999 & 2000 & 2001 & 2002 & 2003 & 2004 & 2005 & 2006 & 2007 & 2008 & 2009 \\
\hline Vaccination coverage $^{a}$ & 110,68 & 77,74 & 80,47 & 86,77 & 97,66 & 91,93 & 89,85 & 99,29 & 78,22 & 86,55 & 87,59 \\
\hline
\end{tabular}

avalues expressed as \%. Source: Brazilian National Immunization Program.

The Brazilian National Immunization Campaign for Seniors began in 1999. The target population was individuals 65 years of age or older, and $87.3 \%$ of the estimated population in this age group was vaccinated. In the subsequent year, vaccination was made available to all Brazilians 60 years of age or older. However, vaccination coverage decreased to $71.8 \%$. In 2001 , a redoubling of efforts in the campaign resulted in nationwide vaccination coverage of $82.1 \%{ }^{(5)}$ These data are similar to those observed in Brasília.

Studies have shown that adherence to influenza vaccination campaigns is lowest among elderly individuals between 60 and 69 years of age, especially among those with a higher level of education. ${ }^{(6)}$ In that age group, the PMR for respiratory diseases showed no change after the vaccine intervention. It is possible that the side effects of the vaccine, such as myalgia, low-grade fever, and malaise, can be mistaken for influenza, leading those individuals to believe that the vaccine does not protect them against influenza or even reinforcing the myth that the influenza vaccine can cause influenza. ${ }^{(5)}$

A number of factors are involved in the behavior of influenza and affect the complexity of the data obtained. The influenza virus exhibits antigenic variations that result in partial changes in its genetic structure. This phenomenon enables the cyclical occurrence of the disease in the population; this is possible because of the high genetic variability and adaptability of the virus. $^{(3,14)}$ Therefore, annual influenza vaccination is necessary. ${ }^{(2)}$

In Brazil, the seasonality of influenza varies from region to region, seasonal differences in 
frequency being more marked in regions with well-defined seasons-higher frequencies being observed in the colder months in areas with a temperate climate and in the wetter months in areas with a tropical climate. Seasonal influenza can manifest in annual outbreaks of varying size, severity, and extent that complicate the accurate diagnosis of the condition and the accurate determination of the efficacy of prophylaxis. ${ }^{(14)}$

In addition to the factors implicated in the difficulty in controlling influenza, another aspect that deserves attention is the increase in the circulation of other viruses with respiratory tropism. In addition to the influenza virus, the viruses most commonly associated with pulmonary infections and their complications include Respiratory syncytial virus, parainfluenza, adenovirus, rhinovirus, and metapneumovirus, the last having been identified most recently. ${ }^{(15,16)}$ This could explain the fluctuations observed in the present study, particularly in the $\geq 80$-year age group, because that group is more susceptible to infectious diseases.

The immune system also plays an important role in disease onset and maintenance. The aging of the immune system, known as immunosenescence, is associated with the gradual deterioration of immune function, thereby increasing susceptibility to infections, autoimmune diseases, and cancer. This deterioration of immune function is associated with changes that can occur in each phase of the development of the immune response. ${ }^{(4)}$ The effectiveness of influenza vaccination in preventing disease is lower in elderly individuals than in younger adults, the effectiveness of vaccination ranging from $30 \%$ to $40 \%$ in the former group, compared with $70 \%$ to $90 \%$ in the latter. ${ }^{(5,17,18)}$

An ecological analysis has limited ability to generate causal hypotheses. In the present study, it is relevant to consider the complexity of establishing respiratory infection as the cause of death in elderly individuals, who frequently have multiple comorbidities. Underreporting or erroneous reporting of the cause of death occurs more often in the elderly population. In Brasilia, the CMR can be used reliably, since the death records in Brasília cover almost all occurrences (95\%). ${ }^{(19)}$

The present study draws attention to the potential efficacy of the influenza vaccination campaign in reducing mortality from respiratory diseases among elderly individuals residing in
Brasilia. The investments made in health care, with regard to the vaccination campaign, appear to have had a positive impact on the health of this population segment.

\section{References}

1. Portal da Saúde [homepage on the Internet]. Brasília: Ministério da Saúde. [cited 2012 Oct 1]. Available from: http://www.saude.gov.br/svs

2. Forleo-Neto E, Halker E, Santos VJ, Paiva TM, TonioloNeto J. Influenza [Article in Portuguese]. Rev Soc Bras Med Trop. 2003;36(2):267-74.

3. Brasil. Ministério da Saúde. Coordenação Geral do Programa Nacional de Imunizações. Campanha nacional de vacinação do idoso. Informe Técnico. Brasília: Ministério da Saúde; 2009.

4. Santos ZM: Oliveira ML. Avaliação dos conhecimentos, atitudes e práticas dos idosos sobre vacina contra a Influenza, na UBS, Taguatinga, DF,2009. Epidemiol Serv Saúde. 2010;19(3):205-16.

5. Toniolo-Neto, J; Halker, E; Gagliardi ANZ, Kairala M. Vacinas. In: Freitas EV, Py L, Cançado FA, Gorzone ML, editors. Tratado de Geriatria e Gerontologia. Rio de Janeiro: Guanabara Koogan; 2006. p. 856-63.

6. Donalisio MR. Brazilian policy for influenza vaccination and its impact on the health of the elderly. Cad Saude Publica. 2007;23(3):494-5.

7. Beyer WE, de Bruijn IA, Palache AM, Westendorp RG, Osterhaus AD. Protection against influenza after annually repeated vaccination: a meta-analysis of serologic and field studies. Arch Intern Med. 1999;159(2):182-8.

8. Nichol KL, Wuorenma J, von Sternberg T. Benefits of influenza vaccination for low-, intermediate-, and high-risk senior citizens. Arch Intern Med. 1998;158(16):1769-76.

9. Francisco PM, Donalisio MR, Lattorre Mdo R. Impact of influenza vaccination on mortality by respiratory diseases among Brazilian elderly persons [Article in Portuguese]. Rev Saude Publica. 2005;39(1):75-81.

10. Façanha MC. Influenza vaccination of individuals over the age of 60: impact on hospital admissions and deaths from respiratory and circulatory diseases in Fortaleza, Brazil. J Bras Pneumol. 2005; 31(5):415-20.

11. DATASUS [homepage on the Internet]. Brasilia: Ministério da Saúde. [cited 2010 Sep 1]. Informações demográficas e socioeconômicas. Available from: http://www2.datasus. gov.br/DATASUS/index.php?area $=0206$

12. Instituto Brasileiro de Geografia e Estatística. Pesquisa Nacional por Amostra de Domicílios (PNAD). Rio de Janeiro: IBGE; 2004.

13. Campos EC, Sudan LC, Mattos ED, Fidelis R. Factors associated with influenza vaccination among the elderly: a cross-sectional study in Cambé, Paraná State, Brazil [Article in Portuguese]. Cad Saude Publica. 2012;28(5):878-88.

14. Secretaria de Vigilância em Saúde. 0 desafio da influenza: epidemiologia e organização da vigilância no Brasil. Boletim Eletrônico Epidemiológico. 2004;4(1):1-7.

15. Stockton J, Stephenson 1, Fleming D, Zambon M. Human metapneumovirus as a cause of community-acquired respiratory illness. Emerg Infect Dis. 2002;8(9):897-901.

16. Boivin G, Abed Y, Pelletier G, Ruel L, Moisan D, Côté S, et al. Virological features and clinical manifestations associated with human metapneumovirus: a new paramyxovirus responsible for acute respiratory-tract infections in all age groups. J Infect Dis. 2002;186(9):1330-4. 
17. Tatum PE, Mehr DR. Prevention and Health Promotion. In: Landefeld CS, Palmer RM, Johnson MA, Johnston $\mathrm{CB}$, Lyons WL, editors. In: Current geriatric diagnosis and treatment. New York: MacGraw-Hill; 2004. p.7-15.

18. Francisco PM, Donalisio MR, Barros MB, César CL, Carandina L, Goldbaum M. Factors associated with vaccination against influenza in the elderly [Article in Portuguese]. Rev Panam Salud Publica. 2006;19(4):259-64.

19. Paes NA, Albuquerque ME. Evaluation of population data quality and coverage of registration of deaths for the Brazilian regions [Article in Portuguese]. Rev Saude Publica. 1999;33(1):33-43.

\section{About the authors}

\section{Francisca Magalhães Scoralick}

Geriatrician. Hospital Regional da Asa Norte - HRAN, North Wing Regional Hospital - Escola Superior de Ciências da Saúde/ Secretaria de Estado da Saúde - ESCS/SES, Graduate School of Health Sciences/State Department of Health - and Master's Student in the Graduate Program in Health Sciences, Federal University of Brasília, Brasilia, Brazil.

\section{Luciana Paganini Piazzolla}

Professor. Catholic University of Brasília, Brasília, Brazil.

\section{Liana Laura Pires}

Professor. Catholic University of Brasília School of Medicine, Brasília, Brazil.

\section{Cleudsom Neri}

Professor. University of Brasília School of Medicine, Brasília, Brazil.

\section{Wladimir Kummer de Paula}

Neurologist. Department of Neurology, Dona Helena Hospital, Joinville, Brazil. 